\title{
Vegetable-Oil-Based Hyperbranched Polyester-Styrene Copolymer Containing Silver Nanoparticle as Antimicrobial and Corrosion-Resistant Coating Materials
}

\author{
Manawwer Alam, ${ }^{1}$ Mohammed Rafi Shaik, ${ }^{2}$ and Naser M. Alandis ${ }^{2}$ \\ ${ }^{1}$ Research Center College of Science, King Saud University, P.O. Box 2455, Riyadh 11451, Saudi Arabia \\ ${ }^{2}$ Department of Chemistry, College of Science, King Saud University, P.O. Box 2455, Riyadh 11451, Saudi Arabia \\ Correspondence should be addressed to Manawwer Alam; malamiitd@gmail.com
}

Received 9 May 2013; Accepted 9 July 2013

Academic Editor: Mallikarjuna Nadagouda

Copyright ( 2013 Manawwer Alam et al. This is an open access article distributed under the Creative Commons Attribution License, which permits unrestricted use, distribution, and reproduction in any medium, provided the original work is properly cited.

\begin{abstract}
Pongamia oil (PO) was converted to Pongamia oil hydroxyl (POH) via epoxidation process. The esterification of POH with linolenic acid was carried out to form hyperbranched polyester (HBPE), and further styrenation was performed at the conjugated double bond in the chain of linolenic acid. After styrenation, silver nanoparticle was added in different weight percentages (0.1-0.4 wt\%). The structural elucidation of POH, HBPE, and HBPE-St was carried out by FT-IR, ${ }^{1} \mathrm{H}-\mathrm{NMR}$, and ${ }^{13} \mathrm{C}-\mathrm{NMR}$ spectroscopic techniques. Physicochemical and physicomechanical analyses were performed by standard method. Thermal behavior of the HBPESt was analyzed by using thermogravimetric analysis (TGA) and differential scanning calorimetry (DSC). The coatings of HBPE-St were prepared on mild steel strips. The anticorrosive behavior of HBPE-St resin-based coatings in acid, saline, and tap water was evaluated, and the molecular weight of HBPE-St was determined by gel permeation chromatography (GPC). The antibacterial activities of the HBPE-St copolymers were tested in vitro against bacteria and fungi by disc diffusion method. The HBPE-St copolymers exhibited good antibacterial activities and can be used as antimicrobial and corrosion-resistant coating materials.
\end{abstract}

\section{Introduction}

Vegetable oils (VO) have been used in the preparation of paints, varnishes, printing inks, and other protective/decorative coatings. After various modifications, they show desired coating properties such as fast drying, good adhesion and resistance to alkali, acid, and marine environments. Semidrying and nonconjugated drying oils are needed to be mixed with other moieties like styrene, methyl methacrylate, vinyl acetate, poly vinyl alcohol, and others to obtain better products [1-8].

At present, different vo are used like linseed, Soybean, Rubber Seed oil, Jatropha, and Castor and these are modified in terms of different types of polymers to improve their properties according to their applications [9-12]. Pongamia glabra (PO) is one of the most nonedible VO belonging to the family Leguminasea. It is a medium-sized tree with a shortcrooked trunk and broad crown of spreading or drooping branches. The tree is valued for shade, ornamental purpose, seed oil, fodder, and green manure. The oil content $28-32 \%$ has good amount of unsaturation with a higher concentration of oleic acid. PO is reportedly used in biodiesel as well as in surface coatings $[11,13,14]$.

Antimicrobial property of surface coating materials is unquestionably the priority for researchers of material science in modern world. Antimicrobial polymers containing silver nanoparticles (NPs) are subject of great attraction to academic and industry due to their novelty in being a durable biocidal material with high temperature stability and low volatile contents [15-19]. Antibacterial coatings can be easily applied to mild steel surfaces to protect the environment from harmful microorganisms.

Currently, in the area of paint and coatings technology, NPs are used to improve the coating properties in terms of adhesion, impact resistance, scratch hardness, gloss, and antimicrobial properties [16]. The NPs with dimensions of 

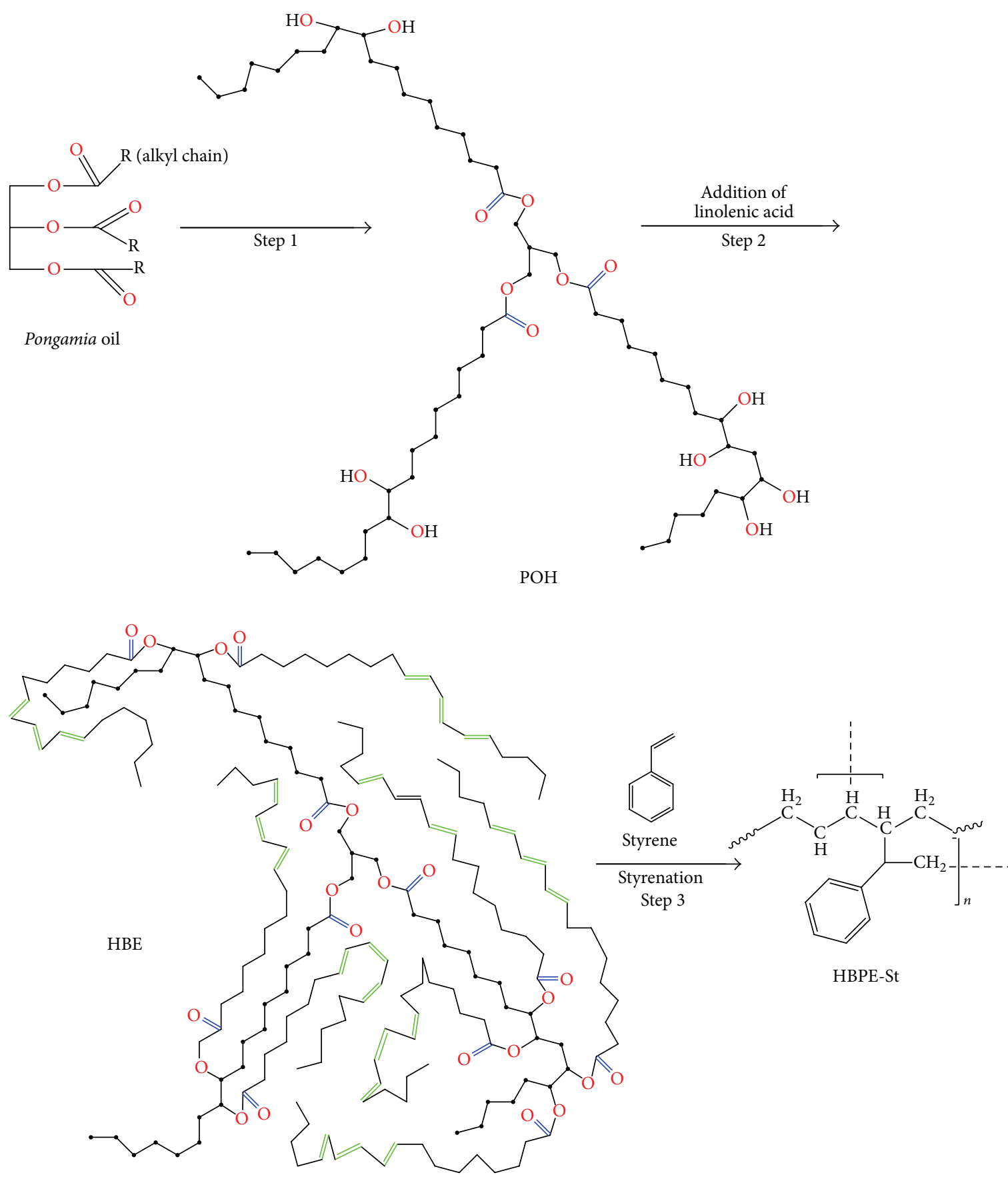

SCHEME 1: Schemes synthesis of hyperbranched polyester-styrene copolymer.

$<100 \mathrm{~nm}$ are able to reinforce polymer matrix without disturbing the transparency and other properties of the coatings. NPs are most commonly used in coatings such as $\mathrm{SiO}_{2}, \mathrm{TiO}_{2}$, $\mathrm{Al}_{2} \mathrm{O}_{3}$, and others. $\mathrm{TiO}_{2}$ and $\mathrm{ZnO}$ nanoparticles are mostly used as UV-blocking agents, whereas $\mathrm{Al}_{2} \mathrm{O}_{3}$ and $\mathrm{SiO}_{2}$ are used to improve scratch hardness and abrasion resistance of the coatings. Silver NPs are also used for antimicrobial and antiseptic properties [20-22].

In this paper, for the first time, we report Pongamia oil conversion to hyperbranched polyester and copolymerization with styrene, which was further embedded with silver nanoparticle to form nanocomposites coatings. These coatings were found to possess good physicomechanical properties like scratch hardness, impact resistance, bending test, gloss, and good antimicrobial properties. The resins were characterized by FT-IR, ${ }^{1} \mathrm{H}-\mathrm{NMR}$, and ${ }^{13} \mathrm{C}-\mathrm{NMR}$ spectroscopic techniques. Molecular weight of HBPE-St was determined by GPC. The thermal behavior was studied with the help of TGA and DSC. HBPE-St coated mild steel was used for corrosion tests in different (acidic, saline, and tap water) corrosive media through potentiodynamic polarization technique. 


\section{Experimental}

2.1. Materials. Pongamia glabra seeds were finely powdered in a grinder and oil was extracted from seeds powder in a soxhlet apparatus by refluxing in petroleum ether (BP. $60-80^{\circ} \mathrm{C}$ ). PO was separated from the solvent in a rotary evaporator and purified. The fatty acid composition of the oil was determined using its methyl ester on a Perkin Elmer Model 716, Column: SUPLEOWAX ( 0.32 id and 30 meter long), gas liquid chromatography (GLC) with FID detector. The injection temperature was $260^{\circ} \mathrm{C}$; nitrogen/helium and hydrogen were used as the carrier gas at a flow rate of $300 \mathrm{~mL} / \mathrm{min}$ and $30 \mathrm{~mL} / \mathrm{min}$. The fatty acid composition of PO was found as oleic $53.10 \%$, linoleic $20.00 \%$, palmitic $11.25 \%$, and stearic $8.08 \%$ [14]. Silver NPs (average diameter $10 \pm 4 \mathrm{~nm}$, Sigma-Aldrich), Acetic acid (Polyscience, Warrington, PA), sulphuric acid, sodium hydroxide, sodium chloride, phthalic acid (PA), linoleic acid (Iodine value 155), styrene, and boron trifluoride etherate (BDH Chemicals, Ltd Poole, England) were used as received.

2.2. Synthesis of Pongamia Oil Hydroxyl (POH). PO $40 \mathrm{~mL}$, benzene $40 \mathrm{~mL}$, glacial acetic acid $8.0 \mathrm{~mL}$, and $1 \mathrm{~mL}$ of sulphuric acid diluted to $50 \%$ with deionized water were taken in a three-necked round-bottomed flask equipped with a mechanical stirrer, dropping funnel, and thermometer. The flask was immersed in a cold water bath; $48.5 \mathrm{~mL}$ of $30 \%$ hydrogen peroxide was added dropwise with continuous stirring. The temperature of the reaction mixture was kept at $0-5^{\circ} \mathrm{C}$ during the addition of hydrogen peroxide. The temperature was raised up to $60^{\circ} \mathrm{C}$. The progress of the reaction was monitored by determining the epoxy equivalent (EE) at regular intervals. When EE approached 350, then the reaction temperature was further increased to $80^{\circ} \mathrm{C}$. Hydroxyl value was used to monitor the course of the reaction along with EE and TLC. The synthesized POH was cooled and dissolved in diethyl ether. The ethereal solution of the final product was washed with sodium bicarbonate aqueous solution, and separated in two layers then the aqueous layer was discarded and ethereal layer was taken in round-bottom flask. Ether was removed with the help of rotary vacuum evaporator at $45^{\circ} \mathrm{C}[23]$.

2.3. Synthesis of Hyperbranched Ester (HBPE). $\mathrm{POH}$ $(0.01 \mathrm{~mol})$ and linolenic acid $(0.06 \mathrm{~mol})$ were placed in four-necked round-bottom flask fitted with Dean Stark trap, nitrogen inlet tube, thermometer, and a magnetic stirrer. The temperature of the reaction was maintained at $150^{\circ} \mathrm{C}$ and refluxed until the calculated amount of water was collected in Dean Stark trap. The progress of the reaction was monitored by TLC as well as hydroxyl value determination at regular intervals.

2.4. Styrenation of HBPE with Silver Nanoparticles (HBPESt). HBPE and styrene different phr (75-90) and $0.1 \mathrm{wt} \%$ of $\mathrm{BF}_{3} \cdot \mathrm{OEt}_{2}$ initiator of styrene were placed in three-necked round-bottom flask with condenser, nitrogen inlet tube, thermometer, and a magnetic stirrer. The temperature of

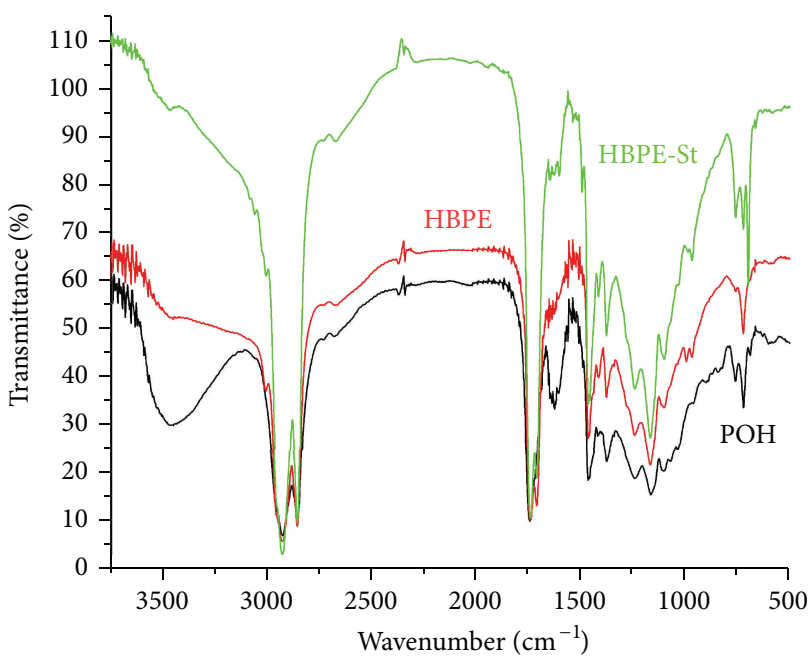

FIgURE 1: FT-IR spectrum of POH, HBE, and HBPE-St.

the reaction was maintained at $75^{\circ} \mathrm{C}$ and refluxed until the desired viscosity of copolymer was achieved. After completion of the reaction, silver NPs were added to the copolymer in various concentrations, namely, $0.1 \mathrm{wt} \%, 0.2 \mathrm{wt} \%, 0.3 \mathrm{wt} \%$, and $0.4 \mathrm{wt} \%$. The dispersion was done mechanically by using a stirrer at the speed of $200 \mathrm{rpm}$ for $30 \mathrm{~min}$. Only $0.3 \mathrm{wt} \% \mathrm{NPs}$ showed the best dispersion in the polymer matrix.

\section{Results and Discussion}

The chemical reactions involved in the synthesis of $\mathrm{POH}$, HBPE, and HBPE-St are given in Scheme 1, steps 1, 2, and 3 , respectively. HBPE was synthesized by chemical reaction between $\mathrm{POH}$ and linolenic acid. The conjugated double bonds of HBPE were further treated with styrene and followed by the addition of $0.3 \%$ (predetermined) silver NPs.

\subsection{Spectral Analysis}

POH: FT-IR, $\left(\mathrm{cm}^{-1}\right): 3481\left(\mathrm{OH}\right.$ attached to $\left.\mathrm{CH}_{2}\right) ; 1743$ (C=O ester); $2854\left(\mathrm{CH}_{2}\right.$, symmetrical); $2924\left(\mathrm{CH}_{2}\right.$, asymmetrical); 1618, 3010 ( $-\mathrm{CH}=\mathrm{CH}-) ; 1242,(-\mathrm{O}-$ $(\mathrm{C}=\mathrm{O})-\mathrm{O}-\mathrm{str}) ; 1101$ (-O-C-C-, str, ester) (Figure 1).

${ }^{1} \mathrm{H}-\mathrm{NMR}, \mathrm{CDCl}_{3}, \delta$, ppm: $1.26-1.21\left(-\mathrm{CH}_{2}\right) ; 2.20-1.88$ $\left(-\mathrm{CH}_{2}\right.$ attached $\left.\mathrm{CH}\right) ; 4.13\left(-\mathrm{CH}_{2}\right.$ attached $\left.\mathrm{CH}\right) ; 5.31$ $(\mathrm{CHOH}) ; 0.85\left(-\mathrm{CH}_{3}\right)$ (Figure 2$)$.

${ }^{13} \mathrm{C}-\mathrm{NMR}, \mathrm{CDCl}_{3}, \delta$, ppm: $14\left(-\mathrm{CH}_{3}\right) ; 29-22\left(-\mathrm{CH}_{2}\right)$; $25.4\left(-\mathrm{CH}_{2}\right.$ attached to double bond $) ; 172,173(\mathrm{C}=\mathrm{O}$, ester); $129-130$ ( $-\mathbf{C H}=\mathbf{C H}-)$; $57(\mathbf{C H O H})$; (Figure 5).

HBPE: FT-IR, $\left(\mathrm{cm}^{-1}\right)$ : 1242, $1166(-\mathrm{O}-(\mathrm{C}=\mathrm{O})-\mathrm{O}-$ str); $2854\left(\mathrm{CH}_{2}\right.$, symmetrical $) ; 2924\left(\mathrm{CH}_{2}\right.$, asymmetrical); 1739, 1710 ( $\mathrm{C}=\mathrm{O}$ ester $) ; 3007$ ( $-\mathrm{CH}=\mathbf{C H}-)$ (Figure 1).

${ }^{1} \mathrm{H}-\mathrm{NMR}, \quad \mathrm{CDCl}_{3}, \quad \delta, \quad$ ppm: $1.23-1.28 \quad\left(-\mathrm{CH}_{2}\right)$; 2.00-2.26 (- $\mathrm{CH}_{2}$ attached double bonds); 5.32 $(-\mathrm{CH}=\mathrm{CH}-) ; 0.86-0.87\left(-\mathrm{CH}_{3}\right)$ (Figure 3$)$. 

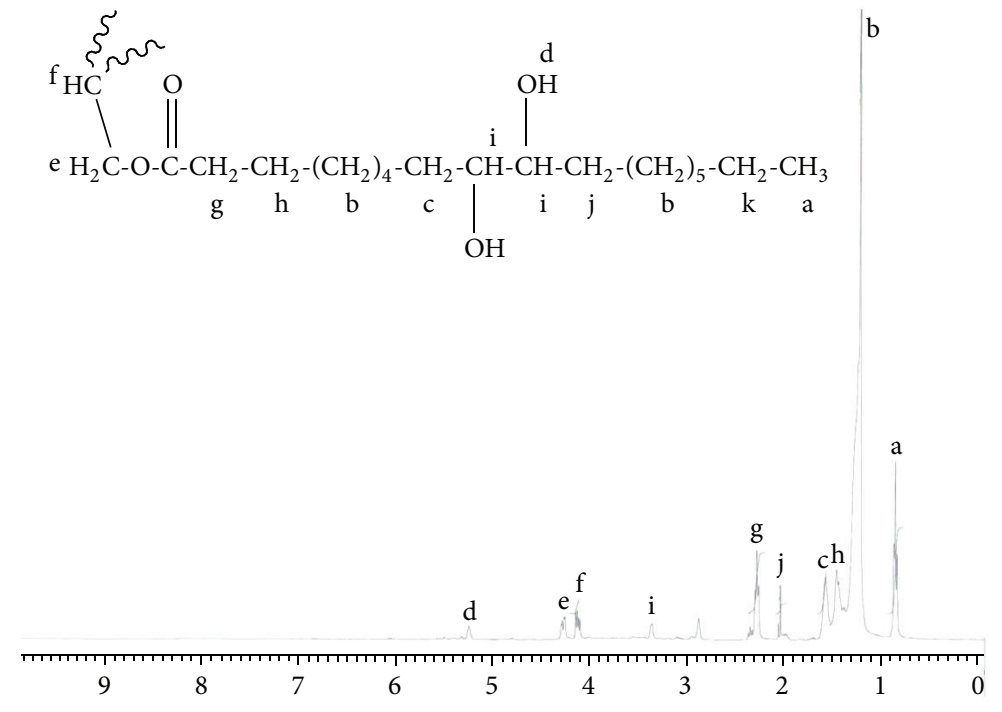

Figure 2: ${ }^{1} \mathrm{H}-\mathrm{NMR}$ spectra of $\mathrm{POH}$.

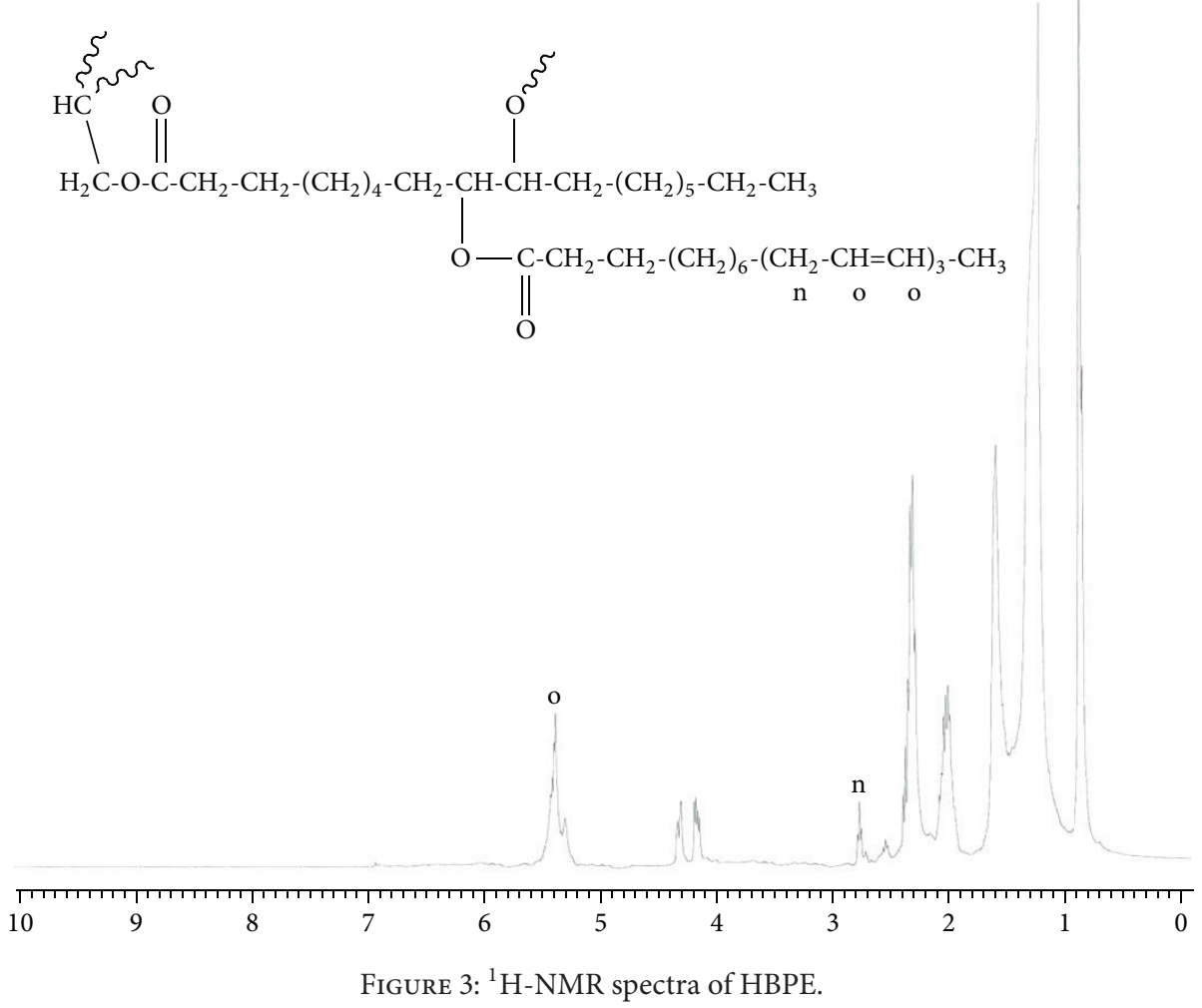

${ }^{13} \mathrm{C}-\mathrm{NMR}, \mathrm{CDCl}_{3}, \delta$, ppm: $14\left(-\mathrm{CH}_{3}\right) ; 29-22\left(-\mathrm{CH}_{2}\right)$; $25.5\left(-\mathrm{CH}_{2}\right.$ attached to double bond $) ; 179,173(\mathrm{C}=\mathrm{O}$, ester); 129, 130 (-CH=CH-); (Figure 6).

HBPE-St: FT-IR, $\left(\mathrm{cm}^{-1}\right)$ : 1739 (C=O ester); 2854 $\left(\mathrm{CH}_{2}\right.$, symmetrical $) ; 2926\left(\mathrm{CH}_{2}\right.$, asymmetrical $) ; 1602$, 3010 (-CH=CH-); 1242, (-O- $(\mathrm{C}=\mathrm{O})-\mathrm{O}-\mathrm{str}) ; 1101$ (O-C-C-, str, ester); 3061, 1628, 1462, 723 (aromatic ring) (Figure 1).
${ }^{1} \mathrm{H}-\mathrm{NMR}, \mathrm{CDCl}_{3}, \delta$, ppm: 1.23-1.28 $\left(-\mathrm{CH}_{2}\right) ; 4.26(-$ $\mathrm{CH}_{2}$-attached $\left.\mathrm{O}\right) ; 2.27-2.34\left(-\mathrm{CH}_{2}\right.$ attached aromatic ring); 5.34 (-CH=CH-); $0.87\left(-\mathrm{CH}_{3}\right) 7.25-7.32$ (aromatic ring) (Figure 4).

${ }^{13} \mathrm{C}-\mathrm{NMR}, \mathrm{CDCl}_{3}, \delta$, ppm: $14\left(-\mathrm{CH}_{3}\right) ; 29.15-29.78$ ($\left.\mathrm{CH}_{2}\right) ; 42\left(\mathrm{CH}_{2}\right.$ and $\mathrm{CH}$ attached to aromatic); 173, $179(\mathbf{C}=\mathrm{O}$, amide $) ; 127-130(-\mathbf{C H}=\mathbf{C H}-$ and aromatic ring) (Figure 7). 


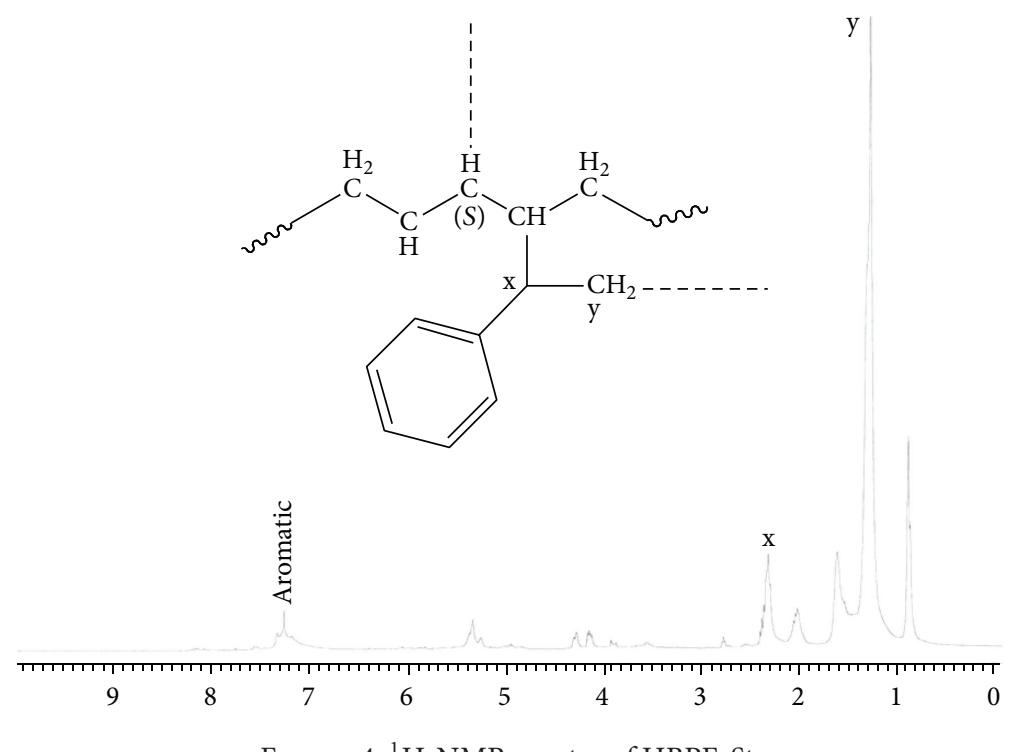

Figure $4:{ }^{1} \mathrm{H}-\mathrm{NMR}$ spectra of HBPE-St.

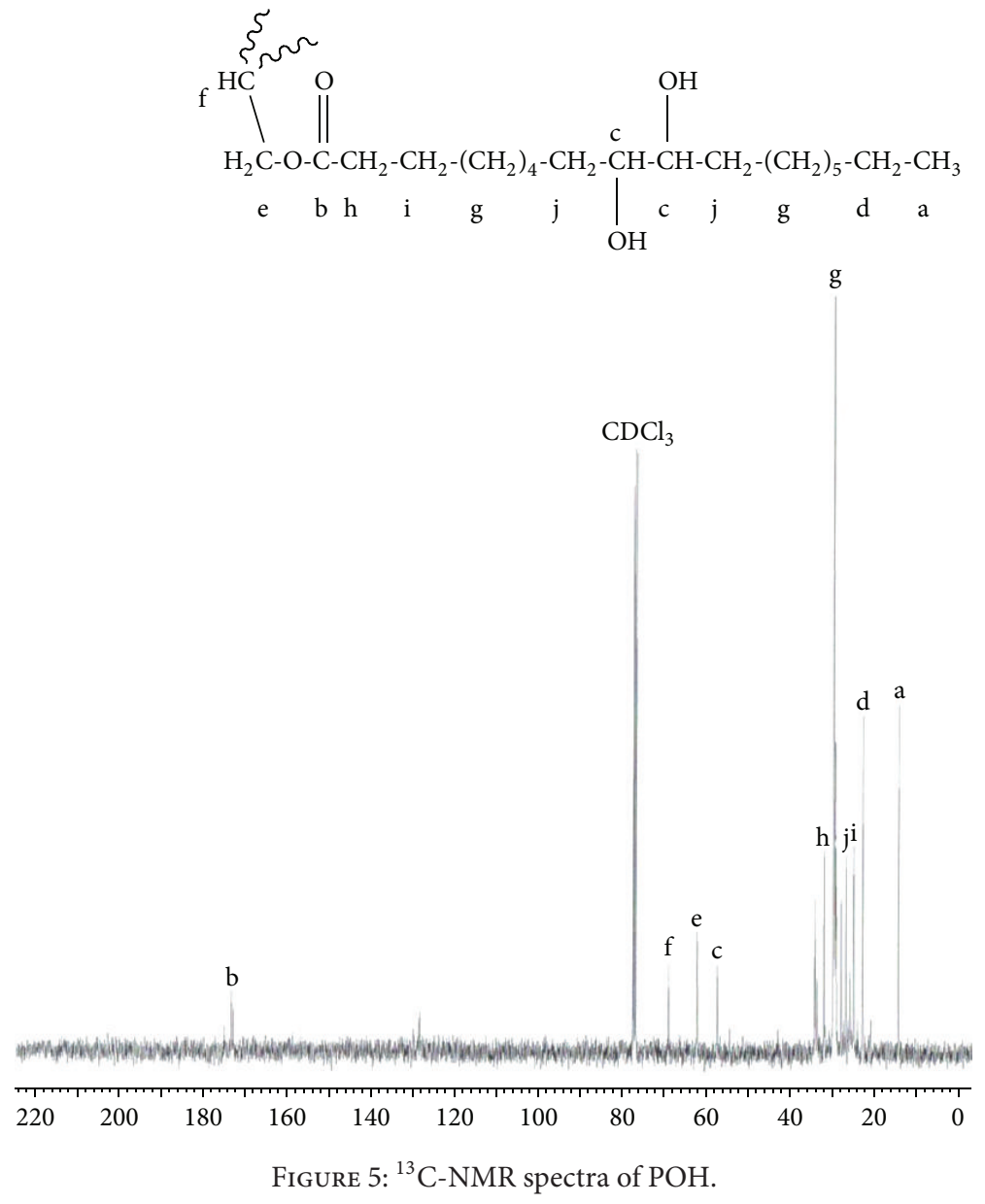




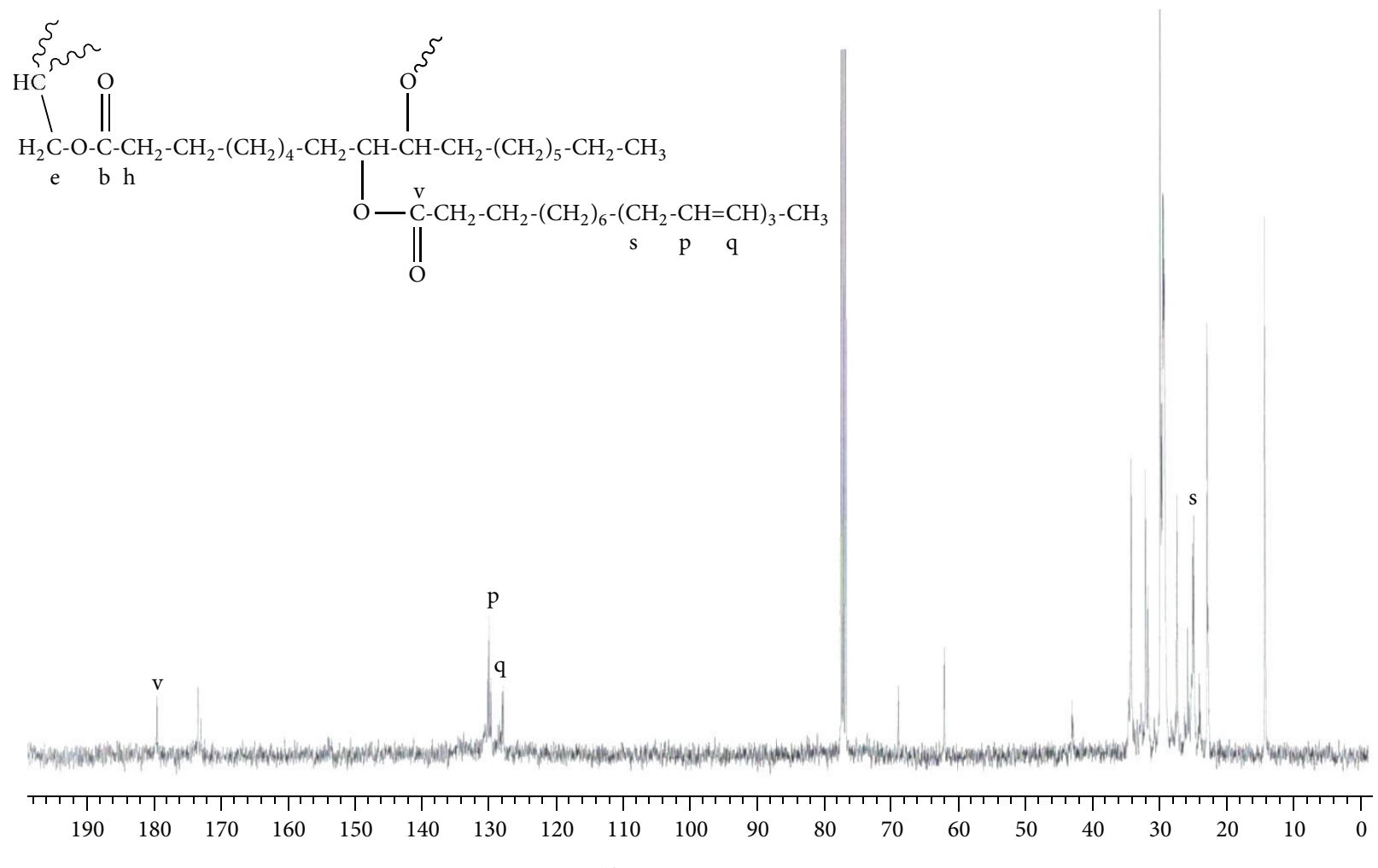

Figure $6:{ }^{13} \mathrm{C}$-NMR spectra of HBPE.

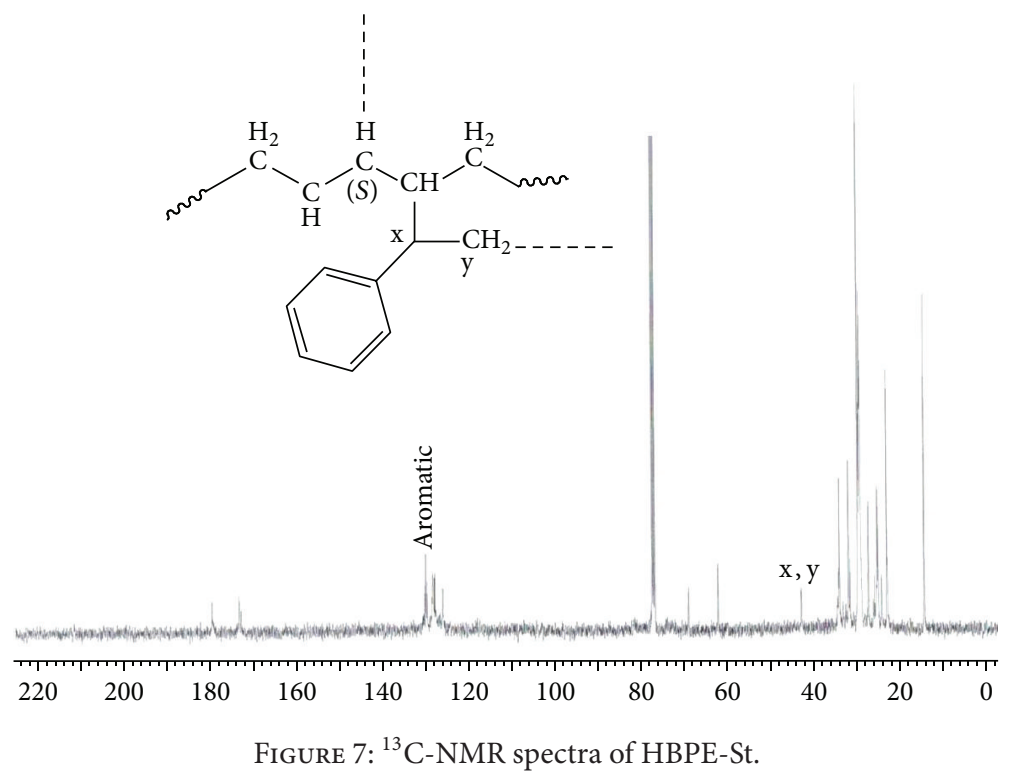

3.2. Instruments and Methods. FT-IR spectra were taken on spectrophotometer (Prestige-21, FTIR-8400S, Shimadzu Corporation, Kyoto, Japan) using $\mathrm{NaCl}$ cell. ${ }^{1} \mathrm{H}-\mathrm{NMR}$ and ${ }^{13} \mathrm{C}-\mathrm{NMR}$ spectra were recorded on a Jeol DPX $400 \mathrm{MHz}$ using deuterated chloroform $\left(\mathrm{CDCl}_{3}\right)$ as a solvent and TMS as an internal standard. Thermal analysis was carried out by thermogravimetric analysis (TGA) and differential scanning calorimetry (DSC) was measured with TGA/DSC1, Mettler Toledo AG, Analytical CH-8603 Schwerzenbach, Switzerland, in nitrogen atmosphere at a heating rate of $10^{\circ} \mathrm{C} /$ minute. The physicochemical properties such as iodine value (ASTM D1959-97), hydroxyl value (ASTM D1957-86), acid value 
TABLE 1: Physicochemical and physicomechanical characterization of resins.

\begin{tabular}{|c|c|c|c|c|c|c|}
\hline Resin code $^{*}$ & $\mathrm{POH}$ & HBPE & HBPE-St75 & HBPE-St80 & HBPE-St85 & HBPE-St90 \\
\hline Hydroxyl value & 39 & 10 & 8.5 & 8 & 7.8 & 7.5 \\
\hline Iodine value & 10 & 160 & 25 & 16 & 15 & 13.8 \\
\hline Refractive index & 1.3811 & 1.3932 & 1.4000 & 1.4010 & 1.4023 & 1.4025 \\
\hline Inherent viscosity & 0.601 & 0.701 & 0.765 & 0.766 & 0.766 & 0.765 \\
\hline Gloss at $45^{\circ}$ & - & - & 65 & 69 & 77 & 80 \\
\hline Impact resistance (ln/inch) & - & - & 150 & 150 & 150 & 150 \\
\hline Bend test (inch) & - & - & $1 / 8$ & $1 / 8$ & $1 / 8$ & $1 / 8$ \\
\hline Scratch hardness (kg) & - & - & 1.8 & 1.9 & 2.2 & 2.1 \\
\hline
\end{tabular}

${ }^{*}$ Last numeral digit indicates the loading of styrene.

(ASTM D555-61), saponification value (ASTM D94), and refractive index were determined by standard laboratory methods.

Molecular weight distribution curve and relative values of number average $(\mathrm{Mw})$ and weight average $(\mathrm{Mn})$ molecular weight of HBPE-St85 were determined by GPC (HTGPC Module 350A,Viscotek, Houston, TX 77060, USA. GPC equipped with CLM6210 HT-GPC column) using polystyrene standard at $35^{\circ} \mathrm{C}$, the flow rate of the carrier solvent, tetrahydrofuran (THF), was $1.0 \mathrm{~mL} / \mathrm{min}$. The molecular weight of HBE-St85 is $4628(\mathrm{Mn}), 7727(\mathrm{Mw})$, and polydispersity index 1.567.

The antibacterial and antifungal activity of HBPE-St 85 was performed by agar diffusion method. The microorganisms used in this study were three bacteria, Bacillus pasteurii, Escherichia coli, Streptococcus, and three fungal strains, Aspergillus niger, Rhizoctonia solani, Fusarium solani. The culture was prepared for antibacterial studies, Nutrient agar: Beef Extract (0.3\%), Peptone (0.5\%), and Agar (1.5\%) in water. $1 \mathrm{wt} \%$ solution of HBPE-St85 in butanone was used for growth studies of bacteria at $27^{\circ} \mathrm{C}$ (incubator temperature). Potato dextrose broth was used for the cultivation of fungi. Antifungal activity of the HBPE-St85 was tested against the pathogenic fungi with concentrations of $100 \mu \mathrm{g} / \mathrm{disc}$ for each and butanone for control. The activity was determined after $72 \mathrm{~h}$ of incubation at $32^{\circ} \mathrm{C}$. The zone of inhibition produced by $1 \mathrm{wt} \%$ HBPE-St 85 was measured.

3.3. Preparation of Coatings. $40 \mathrm{wt} \%$ solution of HBE-St resins were applied by dip technique on commercial available mild steel strips. Scratch hardness (BS 3900), impact resistance (IS : 101 part 5/sec. 3,1988), salt spray test (ASTM D1654), and bend test values (1/8 inch conical mandrel, ASTM-D3281-84) of all the compositions of HBE-St coatings on $70 \times 25 \times 1 \mathrm{~mm}$ and $25 \times 25 \times 1 \mathrm{~mm}$ size strips were performed. The specular gloss of the coatings was determined at $45^{\circ}$ by Gloss-meter (Model RSPT 20; digital instrument, Santa Barba, CA, USA). Elcometer (Model 345; Elcometer instrument, Manchester, UK) was used to measure the coating thickness, which was found to be $100-120 \mu \mathrm{m}$.
Corrosion resistance studies of HBPE-St coated mild steel were performed by using Gill AC (ACM Instruments, Cumbria, UK). The exposed geometric area $1 \mathrm{~cm}^{2}$ for all HBPESt measurements using potentiodynamic polarization, the corrosion current $\left(I_{\text {corr }}\right)$ and corrosion potential $\left(E_{\text {corr }}\right)$ were estimated. Anodic and cathodic branches of polarization curves were recorded with potential charge rate of $1 \mathrm{mVs}^{-1}$. All the samples were in vertical position, and experiments were carried out at ambient temperature. For each result, a minimum of three repetition measurements were taken. The $I_{\text {corr }}$ and $E_{\text {corr }}$ are derived by extrapolating the linear portion of the polarization curve found at potential $\pm 22 \mathrm{mV}$ away from the open circuit potential. The extrapolation leads to an intersection, which correspond to $I_{\text {corr }}$, derived by the SternGeary Equitation, $I_{\text {corr }}=\beta a \beta c /(2.3 R p(\beta a+\beta c))$, where $\beta a$ and $\beta c$ are the anodic and cathodic Tafel coefficients, respectively [24]. The corrosion inhibition efficiency (IE) was calculated by using this equitation, IE $(\%)=\left(\left(I_{o}-I\right) / I_{o}\right) \times 100$, where $I_{o}$ and $I$ are the corrosion currents of bare metal and coated metal, respectively.

3.4. Physicochemical Analysis. Table 1 represents the physicochemical characteristics that indicate the decrease in hydroxyl and iodine values from $\mathrm{POH}, \mathrm{HBPE}$, and subsequently to HBPE-St75, HBPE-St80, HBPE-St85, and HBPESt90 but when iodine value increased, addition of linolenic acid resulted in forming HBPE. The following trends are related to the reaction of $\mathrm{POH}$ with linolenic acid to form HBPE and further reacted with styrene to form HBPE-St copolymer. The increase in refractive index and inherent viscosity from POH, HBPE, HBPE-St75, HBPE-St80, HBPESt 85 , and HBPE-St90 is also observed.

3.5. Coating Properties. Table 1 indicates physicomechanical performance of HBPE-St (75-90 phr). The dry to touch time was found as $30-45 \mathrm{~min}$ and dry to hard time as 14 days. Here, firstly, curing occurs by the solvent evaporation followed by chemical reaction, and secondly, auto-oxidation occurs at functional groups present in the polymer chain. The first process occurs in lower time and makes the coatings dry 
TABLE 2: Corrosion parameter for coated and blank mild strips in different corrosive environments.

\begin{tabular}{lccccc}
\hline Sample code & Medium & $E_{\text {corr }}(\mathrm{mV})$ & $I_{\text {corr }}\left(\mathrm{mA} / \mathrm{cm}^{2}\right)$ & Corrosion rate $(\mathrm{mm} / \mathrm{yr})$ & Inhibition efficiency $(\%)$ \\
\hline Blank & $3.5 \mathrm{wt} \% \mathrm{HCl}$ & -549.37 & 2.224 & 25.770 & - \\
HBPE-St75 & $3.5 \mathrm{wt} \% \mathrm{HCl}$ & -541.32 & $1.099 \times 10^{-4}$ & $1.274 \times 10^{-3}$ & 99.87 \\
HBPE-St80 & $3.5 \mathrm{wt} \% \mathrm{HCl}$ & -531.76 & $1.718 \times 10^{-7}$ & $1.990 \times 10^{-5}$ & 99.99 \\
HBPE-St85 & $3.5 \mathrm{wt} \% \mathrm{HCl}$ & -517.38 & $1.585 \times 10^{-3}$ & $1.838 \times 10^{-3}$ & 99.93 \\
HBPE-St90 & $3.5 \mathrm{wt} \% \mathrm{HCl}$ & -463.78 & $8.485 \times 10^{-3}$ & $9.834 \times 10^{-2}$ & 99.62 \\
Blank & $5.0 \mathrm{wt} \% \mathrm{NaCl}$ & -575.65 & 0.74974 & 8.6894 & - \\
HBPE-St75 & $5.0 \mathrm{wt} \% \mathrm{NaCl}$ & -491.75 & $1.108 \times 10^{-3}$ & $1.284 \times 10^{-2}$ & 99.85 \\
HBPE-St80 & $5.0 \mathrm{wt} \% \mathrm{NaCl}$ & -405.76 & $8.858 \times 10^{-4}$ & $1.027 \times 10^{-2}$ & $9.861 \times 10^{-3}$ \\
HBPE-St85 & $5.0 \mathrm{wt} \% \mathrm{NaCl}$ & -366.68 & $5.920 \times 10^{-4}$ & $1.694 \times 10^{-6}$ & 99.98 \\
HBPE-St90 & $5.0 \mathrm{wt} \% \mathrm{NaCl}$ & -252.57 & $1.462 \times 10^{-7}$ & $2.517 \times 10^{-1}$ & 99.92 \\
Blank & Tape water & -670.47 & $2.171 \times 10^{-2}$ & $1.584 \times 10^{-5}$ & 99.99 \\
HBPE-St75 & Tape water & -360.78 & $1.367 \times 10^{-6}$ & $1.553 \times 10^{-5}$ & - \\
HBPE-St80 & Tape water & -352.96 & $1.340 \times 10^{-6}$ & $1.298 \times 10^{-5}$ & 99.99 \\
HBPE-St85 & Tape water & -276.22 & $1.042 \times 10^{-6}$ & $4.792 \times 10^{-6}$ & 99.93 \\
HBPE-St90 & Tape water & -222.73 & $4.135 \times 10^{-7}$ & 99.95 & 99.80 \\
\hline
\end{tabular}

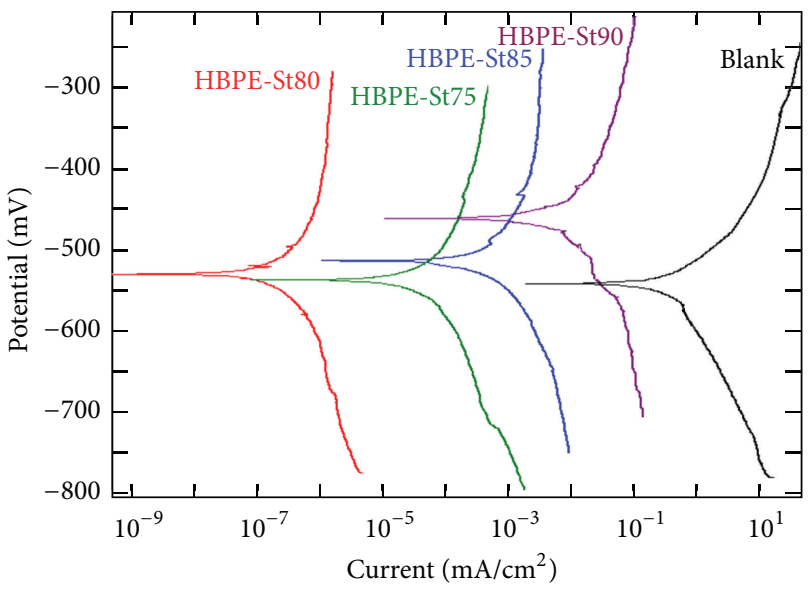

FIGURE 8: Tafel plots of blank and coated with HBPE-St in $3.5 \mathrm{wt} \%$ $\mathrm{HCl}$ solution.

to touch, while the latter reactions are time-consuming and after auto-oxidation reaction coatings become dry to hard. Scratch hardness values were found to increase up to HBPESt85, after that decrease in scratch hardness was observed. All coatings passed $250 \mathrm{lb} /$ in. impact test, which showed good adhesion between coatings and substrate. It was observed that these coatings showed good flexibility (bend test (1/8 in)) due to the presence of alkyl chains. Gloss at $45^{\circ}$ was found to be 69-80.

3.6. Corrosion Test. Corrosion tests process includes the exposure of the panels to $3.5 \mathrm{wt} \% \mathrm{HCl}$ solution, $5 \mathrm{wt} \% \mathrm{NaCl}$ solution, and tap water for $312 \mathrm{~h}, 192 \mathrm{~h}$, and $264 \mathrm{~h}$, respectively. Figure 8 presents the polarization curves in $\mathrm{HCl}$ solution for the bare mild steel and coated with HBPE-St including NPs. It can be seen that there is a significant decrease for both anodic and cathodic currents of the sample HBPE-St relative to the bare mild steel. The decrease in the rate of anodic and cathodic currents is explained by the decreases in the active area of the electrodes, which is a function of coatings. Table 2 shows the tabulated value of $E_{\text {corr }}$, $I_{\text {corr }}$, corrosion rate, and inhibition efficiency after $312 \mathrm{~h}$ of exposure to $3.5 \mathrm{wt} \% \mathrm{HCl}$ solution; the results indicate that HBPE-St75, HBPE-St80, HBPE-St85, and HBPE-St90 coatings demonstrate a decrease of their corrosion current compared to bare mild steel; furthermore, coatings present increases in their polarization resistance. Figure 9 shows typical potentiodynamic polarization for bare mild steel and HBPE-St coated steel after $312 \mathrm{~h}$ immersion in $3.5 \mathrm{wt} \% \mathrm{HCl}$ solution. It was apparent that the polarization curve for mild steel coated with HBPE-St showed remarkable potential shift to noble values compared to bare mild steel immersed in $3.5 \mathrm{wt} \% \mathrm{HCl}$. The various polarization parameters such as $E_{\text {corr }}$ and $I_{\text {corr }}$ obtained from cathodic and anodic curves by extrapolation of Tafel line are given in Table 2 . It should be mentioned that the $E_{\text {corr }}$ values increased significantly for mild steel coated with HBPE-St75, HBPE-St80, HBPESt85, and HBPE-St90. The observation clearly showed that mild steel coated HBPE-St controls both anodic and cathodic reactions, and thus HBPE-St acts as barrier. In the case of mild steel coated with HBPE-St75, HBPE-St80, HBPE-St85, and HBPE-St90, the $E_{\text {corr }}$ values (Table 2) were found to increase with the increase in the amount of styrene in HBPE copolymer. Figure 10 shows the polarization curve recorded for bare mild steel and coated with HBPE-St in tap water. The Tafel region of cathodic and anodic polarization curves was extrapolated and analyzed. $E_{\text {corr }}$ values increased with the increase in the amount of styrene in HBPE copolymer; as a 


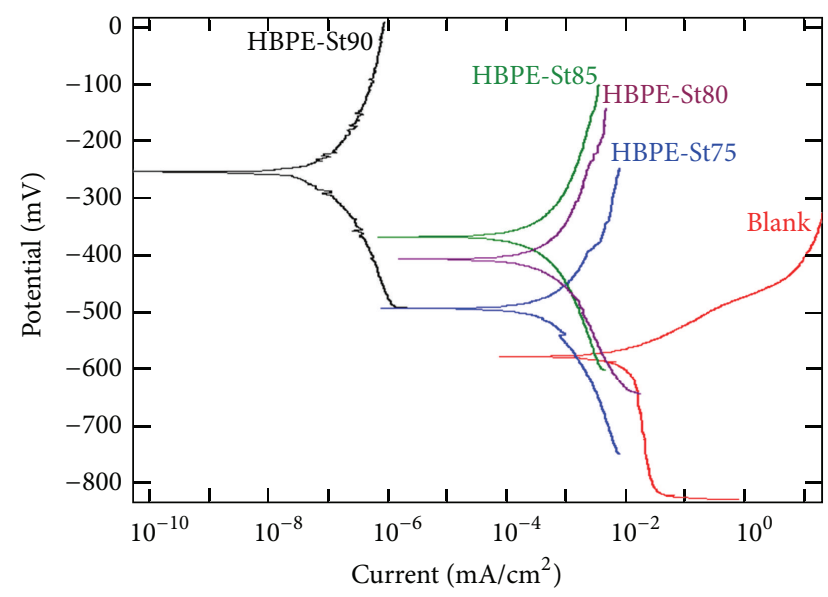

FIgUre 9: Tafel plots of blank and coated with HBPE-St in $5 \mathrm{wt} \%$ $\mathrm{NaCl}$ solution.

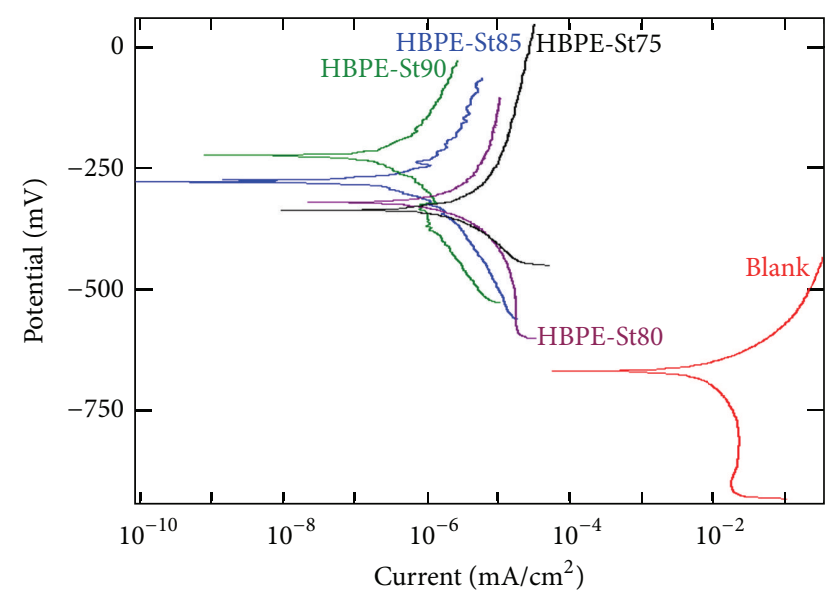

FIGURE 10: Tafel plots of blank and coated with HBPE-St in tap water.

result, HBPE-St coating showed good protection of mild steel. It was observed that HBPE-St comprises a good combination of styrene, ester, silver nanoparticles, and pendant alkyl chains, which facilitate good adhesion to the substrate. The chain enhances the flexibility of coatings. Consequently, the coatings showed good resistance against acid, saline, and tap water. Physicomechanical performance revealed that HBPESt85 showed best performance amongst all compositions.

3.7. Thermal Analysis. Figure 11 shows the TGA thermogram of HBPE-St85; initial 5\% weight loss occurring at $245^{\circ} \mathrm{C}$ corresponds to the release of the entrapped solvent and onset of degradation at this temperature. $10 \%$ weight loss of this resin was observed at $310^{\circ} \mathrm{C}$ and $50 \%$ weight loss at $410^{\circ} \mathrm{C}$. DSC thermogram (Figure 12) of the resin shows $\mathrm{Tg}$ at $110^{\circ} \mathrm{C}$ followed by an endothermic peak centered at $135^{\circ} \mathrm{C}$. TGA thermogram does not show any change in this temperature. This peak may be attributed to the configurational changes in the resin prior to thermal decomposition. An exotherm

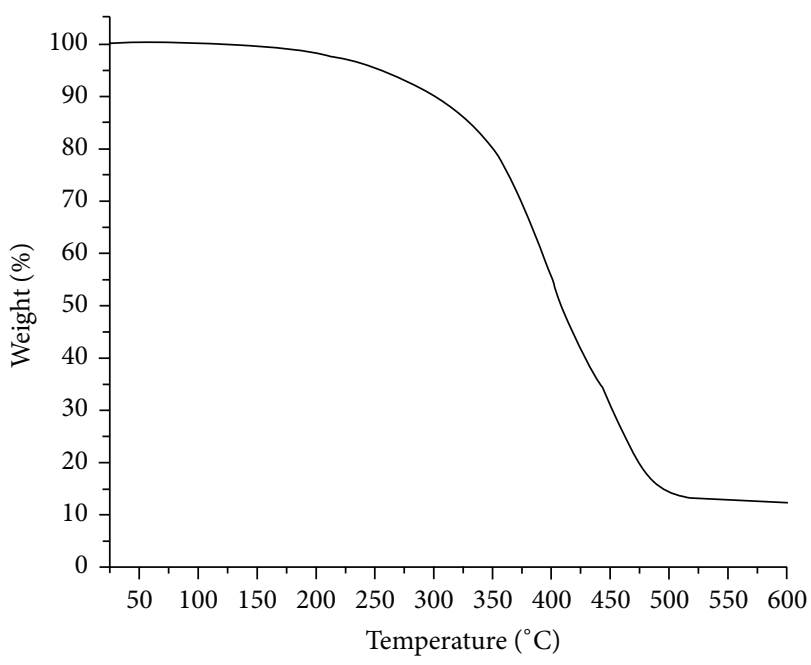

FIGURE 11: TGA thermogram of HBPE-St85.

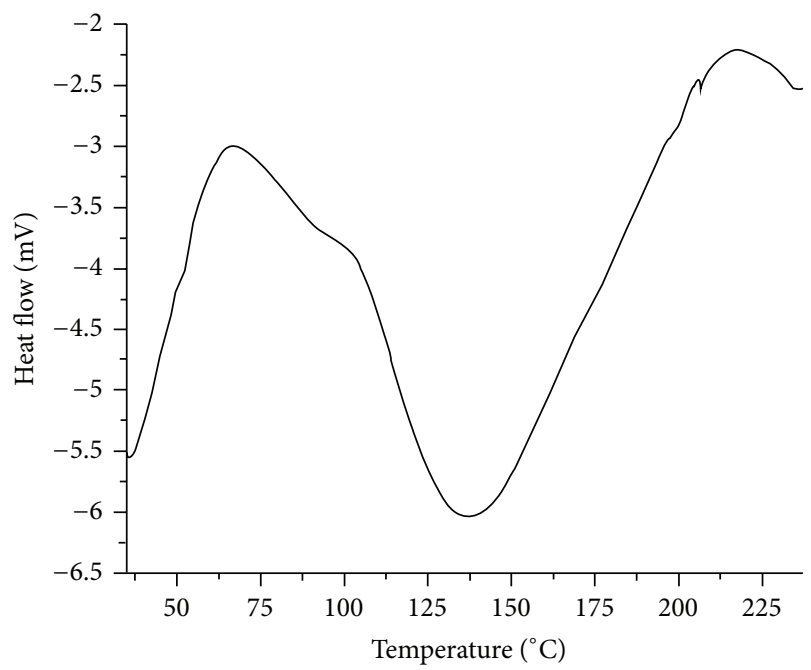

Figure 12: DSC thermogram of HBPE-St85.

ensues beyond $210^{\circ} \mathrm{C}$, in DSC thermogram, which presumably occurs due to the decomposition of the resin as is also observed in TGA thermogram.

3.8. Antimicrobial Studies. The antimicrobial efficacy of the HBPE-St85 against microbes was tested based on zone of inhibition. HBPE-St3(0.3 wt\%NPs in HBPE-St85) was subjected to test the antibacterial behavior against the bacterial species, namely, Bacillus pasteurii, Escherichia coli, and Streptococcus, and fungal species, namely, Aspergillus niger, Rhizoctonia solani, and Fusarium solani. After $48 \mathrm{~h}$ of the incubation at $27^{\circ} \mathrm{C}$, the zones of inhibition of HBPE-St85 against Bacillus pasteurii, Escherichia coli, and Streptococcus are 10,11 , and $8 \mathrm{~mm}$ diameter, respectively, whereas the control did not show any zones of inhibition (Figure 13). The antifungal efficacy of HBPE-St 85 was investigated against the pathogenic fungi Aspergillus niger, Rhizoctonia solani, and Fusarium solani. The efficacy was determined after $72 \mathrm{~h}$ of 

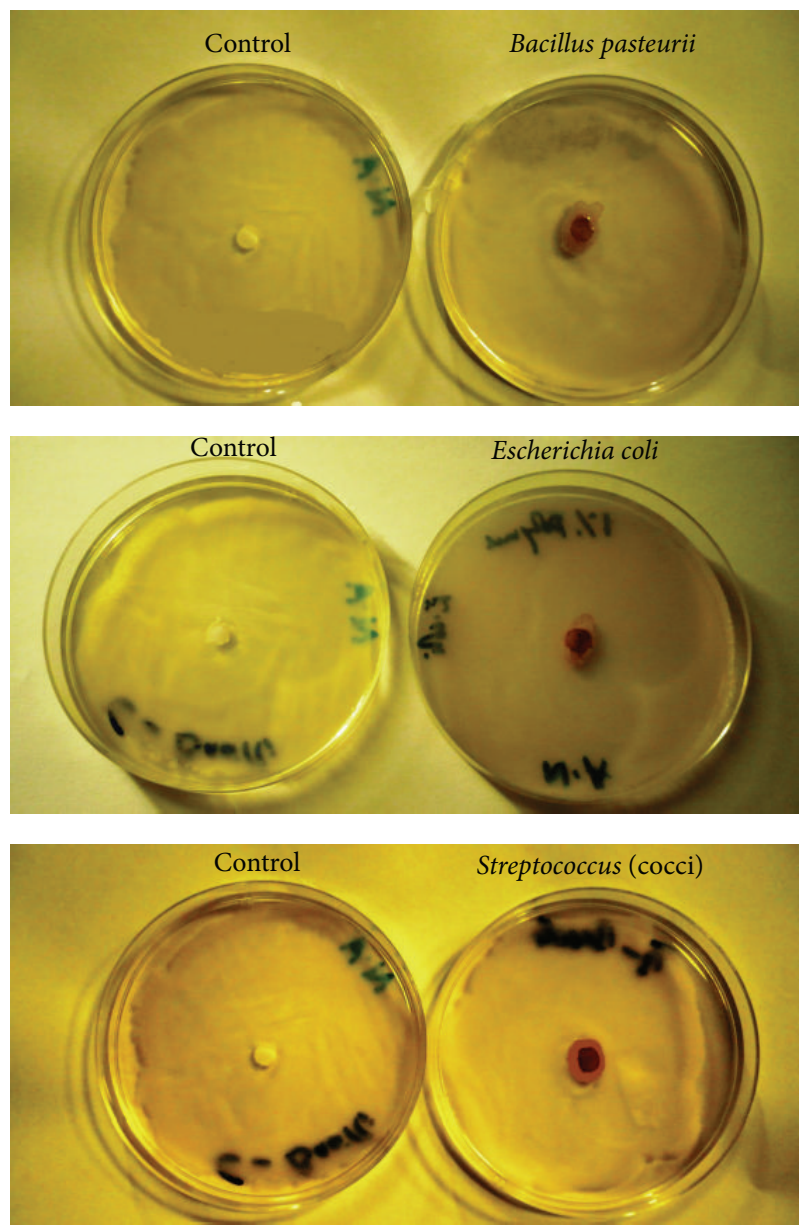

Figure 13: Antibacterial activity of HBPE-St85.

incubation at $32^{\circ} \mathrm{C}$. The diameters of zones of inhibition produced by the HBPE-St 3 against Aspergillus niger, Rhizoctonia solani, and Fusarium solani. are 10, 12, and $9 \mathrm{~mm}$, respectively (Figure 14).

HBPE containing silver NPs showed the good antimicrobial activity. The silver NPs strongly bind with electron donor groups in biological molecules containing oxygen, nitrogen, and sulphur [15]. Silver nanoparticles rupture the bacterial cell wall, so the cell loses its protection. Antimicrobial efficacy depends on the surface area, smaller size with large surface area, to provide more efficient attack against microbes, so silver NPs undergo complex formation with proteins (cell wall) then affect the permeability and respiration leading to the death of the microbes.

\section{Conclusions}

Silver nanoparticles-embedded hyperbranched ester-styrene (HBPE-St) copolymer using Pongamia oil was successfully synthesized and can be used as antimicrobial and anticorrosive protective ecofriendly coating material. A novel combination of silver NPs, ester, and styrene could be achieved by this approach. Among all the compositions, HBPE-St 85
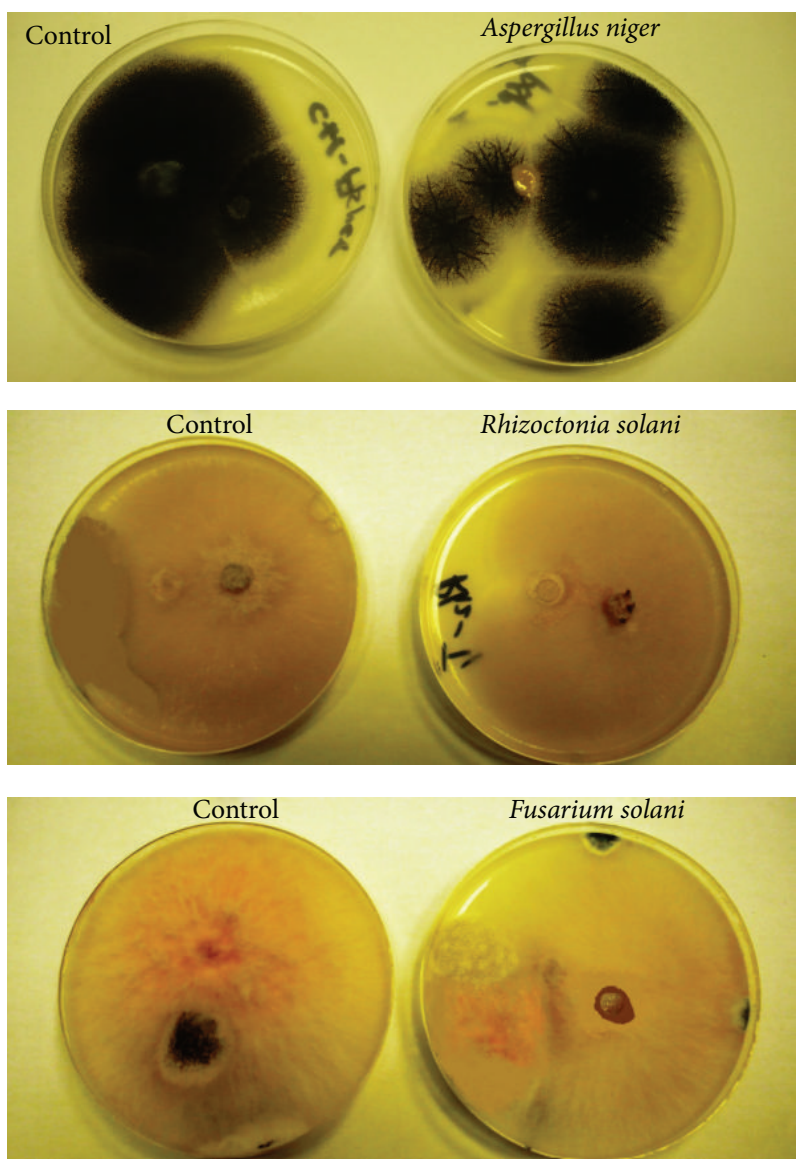

FIgURE 14: Antifungal activity of HBPE-St85.

showed the best physicomechanical and corrosion resistance performance and can be safely used up to $210^{\circ} \mathrm{C}$.

\section{Acknowledgment}

This project was supported by King Saud University, Deanship of Scientific Research, College of Science-Research Center.

\section{References}

[1] T. Akbas, Ü. G. Beker, F. S. Güner, A. T. Erciyes, and Y. Yagci, "Drying and semidrying oil macromonomers. III: stvrenation of sunflower and linseed oils," Journal of Applied Polymer Science, vol. 88, no. 10, pp. 2373-2376, 2003.

[2] M. Alam, E. Sharmin, S. M. Ashraf, and S. Ahmad, "Newly developed urethane modified polyetheramide-based anticorrosive coatings from a sustainable resource," Progress in Organic Coatings, vol. 50, no. 4, pp. 224-230, 2004.

[3] M. Alam, A. R. Ray, S. M. Ashraf, and S. Ahmad, "Synthesis, characterization and performance of amine modified linseed oil fatty amide coatings," Journal of the American Oil Chemists' Society, vol. 86, no. 6, pp. 573-580, 2009.

[4] E. Can, R. P. Wool, and S. Küsefoglu, "Soybean and castor oil based monomers: synthesis and copolymerization with 
styrene," Journal of Applied Polymer Science, vol. 102, no. 3, pp. 2433-2447, 2006.

[5] F. Li and R. C. Larock, "New soyabean oil-styrenedivinylbenzene thermosetting copolymer. I: synthesis and characterization," Journal of Applied Polymer Science, vol. 80, no. 4, pp. 658-670, 2001.

[6] N. Alemdar, A. T. Erciyes, and Y. Yagci, "Styrenation of airblown linseed oil by nitroxide-mediated radical polymerization," Progress in Organic Coatings, vol. 67, no. 1, pp. 55-59, 2010.

[7] P. P. Kundu and R. C. Larock, "Effect of drying catalysts on the properties of thermal copolymers from conjugated linseed oilstyrene-divinylbenzene," Progress in Organic Coatings, vol. 65, no. 1, pp. 10-18, 2009.

[8] P. Badrinarayanan, Y. Lu, R. C. Larock, and M. R. Kessler, "Cure characterization of soybean oil-styrene-divinylbenzene thermosetting copolymers," Journal of Applied Polymer Science, vol. 113, no. 2, pp. 1042-1049, 2009.

[9] E. Sharmin, S. M. Ashraf, and S. Ahmad, "Synthesis, characterization, antibacterial and corrosion protective properties of epoxies, epoxy-polyols and epoxy-polyurethane coatings from linseed and Pongamia glabra seed oils," International Journal of Biological Macromolecules, vol. 40, no. 5, pp. 407-422, 2007.

[10] J. Argyropoulos, P. Popa, G. Spilman, D. Bhattacharjee, and W. Koonce, "Seed oil based polyester polyols for coatings," Journal of Coatings Technology Research, vol. 6, no. 4, pp. 501-508, 2009.

[11] M. Alam and N. M. Alandis, "Development of ambient cured polyesteramide coatings from linseed oil: a sustainable resource," Journal of Polymers and the Environment, vol. 19, no. 2, pp. 391-397, 2011.

[12] F. S. Güner, Y. Yağci, and A. T. Erciyes, "Polymers from triglyceride oils," Progress in Polymer Science, vol. 31, no. 7, pp. 633-670, 2006.

[13] M. Naik, L. C. Meher, S. N. Naik, and L. M. Das, "Production of biodiesel from high free fatty acid Karanja (Pongamia pinnata) oil," Biomass and Bioenergy, vol. 32, no. 4, pp. 354-357, 2008.

[14] S. Ahmad, S. M. Ashraf, F. Naqvi, S. Yadav, and A. Hasnat, "A polyesteramide from Pongamia glabra oil for biologically safe anticorrosive coating," Progress in Organic Coatings, vol. 47, no. 2, pp. 95-102, 2003.

[15] U. Konwar, N. Karak, and M. Mandal, "Vegetable oil based highly branched polyester/clay silver nanocomposites as antimicrobial surface coating materials," Progress in Organic Coatings, vol. 68, no. 4, pp. 265-273, 2010.

[16] A. Kumar, P. K. Vemula, P. M. Ajayan, and G. John, "Silvernanoparticle-embedded antimicrobial paints based on vegetable oil," Nature Materials, vol. 7, no. 3, pp. 236-241, 2008.

[17] H. Deka, N. Karak, R. D. Kalita, and A. K. Buragohain, "Biobased thermostable, biodegradable and biocompatible hyperbranched polyurethane/Ag nanocomposites with antimicrobial activity," Polymer Degradation and Stability, vol. 95, no. 9, pp. 1509-1517, 2010.

[18] U. Konwar and N. Karak, "Hyperbranched polyether core containing vegetable oil-modified polyester and its clay nanocomposites," Polymer Journal, vol. 43, no. 6, pp. 565-576, 2011.

[19] O. Eksik, A. T. Erciyes, and Y. Yagci, "In situ synthesis of oil based polymer composites containing silver nanoparticles," Journal of Macromolecular Science A, vol. 45, no. 9, pp. 698-704, 2008.

[20] S. K. Dhoke and A. S. Khanna, "Effect of nano- $\mathrm{Fe}_{2} \mathrm{O}_{3}$ particles on the corrosion behavior of alkyd based waterborne coatings," Corrosion Science, vol. 51, no. 1, pp. 6-20, 2009.
[21] M. Behzadnasab, S. M. Mirabedini, K. Kabiri, and S. Jamali, "Corrosion performance of epoxy coatings containing silane treated $\mathrm{ZrO}_{2}$ nanoparticles on mild steel in $3.5 \% \mathrm{NaCl}$ solution," Corrosion Science, vol. 53, no. 1, pp. 89-98, 2011.

[22] A. Yabuki, W. Urushihara, J. Kinugasa, and K. Sugano, "Selfhealing properties of $\mathrm{TiO}_{2}$ particle-polymer composite coatings for protection of aluminum alloys against corrosion in seawater," Materials and Corrosion, vol. 62, no. 10, pp. 907-912, 2011.

[23] E. Sharmin, S. M. Ashraf, and S. Ahmad, "Epoxidation, hydroxylation, acrylation and urethanation of Linum usitatissimum seed oil and its derivatives," European Journal of Lipid Science and Technology, vol. 109, no. 2, pp. 134-146, 2007.

[24] I. A. Kartsonakis, E. P. Koumoulos, A. C. Balaskas, G. S. Pappas, C. A. Charitidis, and G. C. Kordas, "Hybrid organic-inorganic multilayer coatings including nanocontainers for corrosion protection of metal alloys," Corrosion Science, vol. 57, pp. 56-66, 2012. 

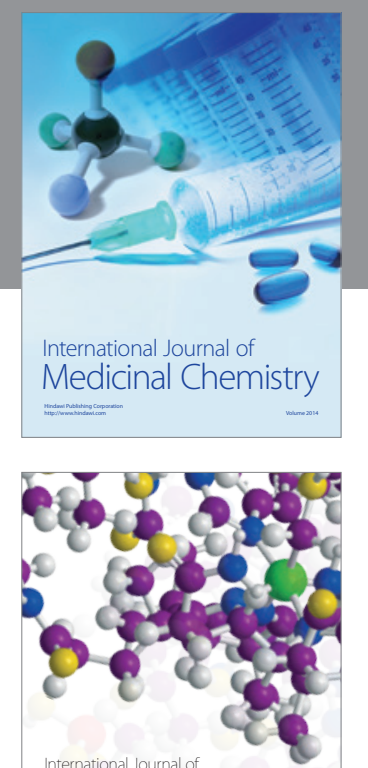

\section{Carbohydrate} Chemistry

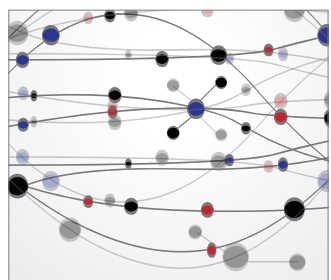

The Scientific World Journal
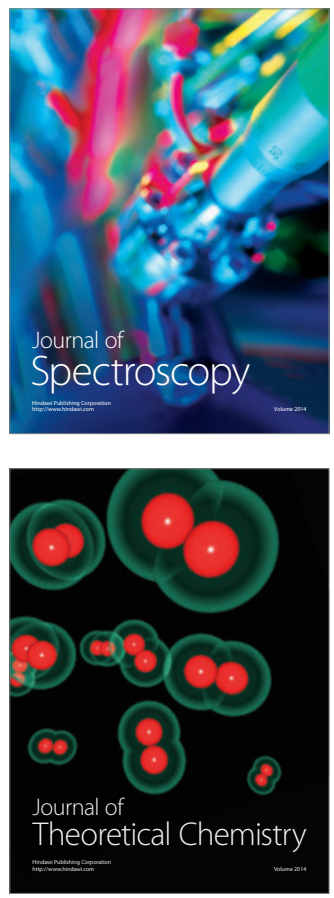
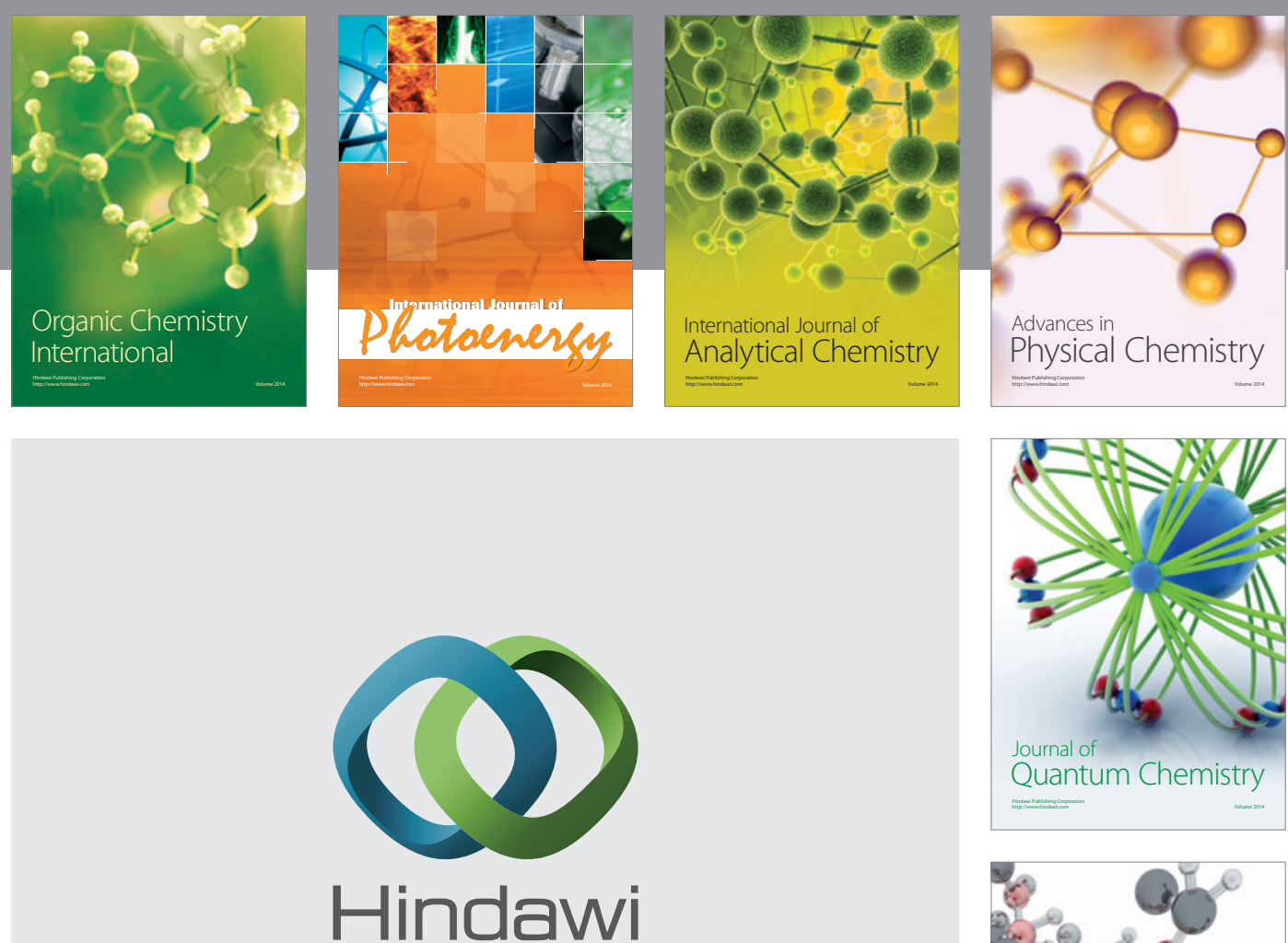

Submit your manuscripts at

http://www.hindawi.com

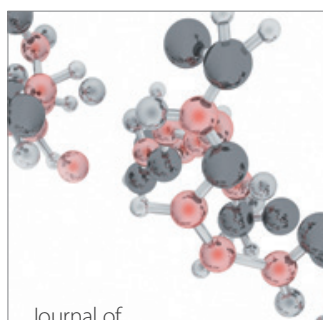

Analytical Methods

in Chemistry

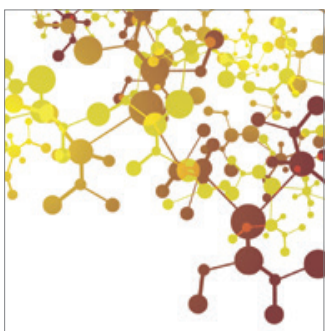

Journal of

Applied Chemistry

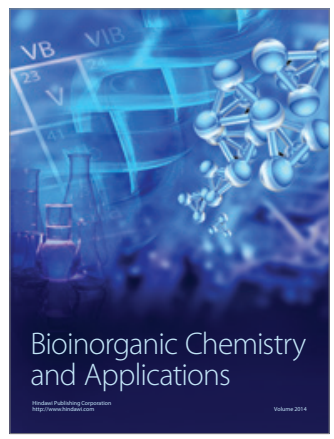

Inorganic Chemistry
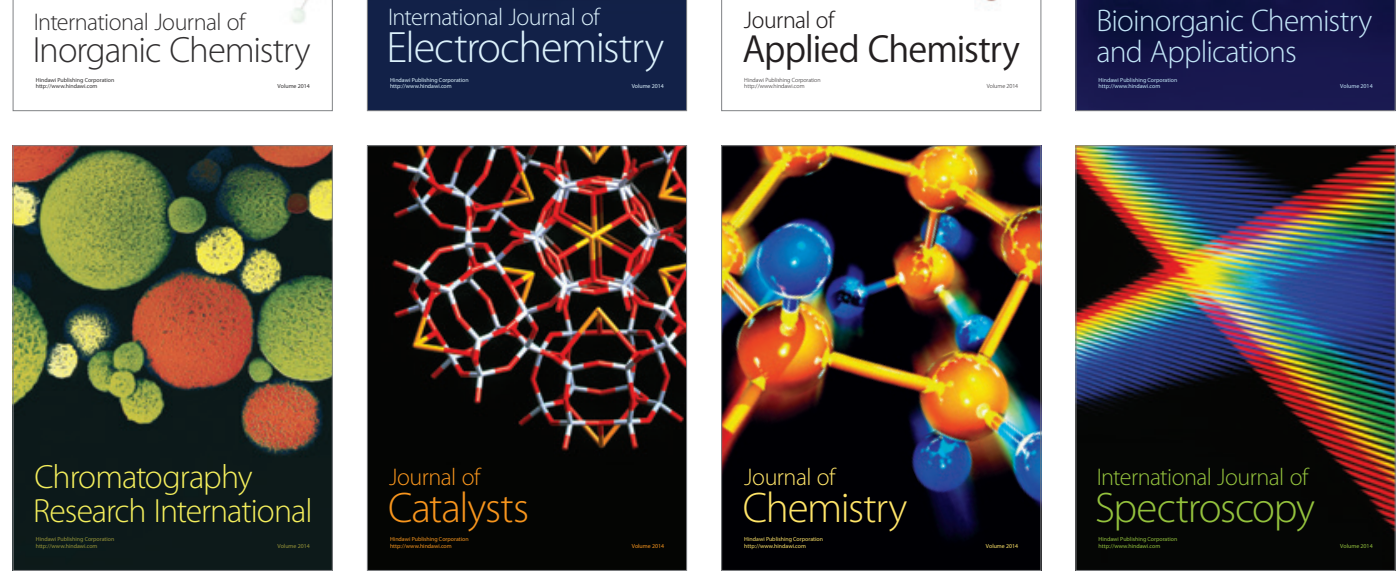